\title{
HOW DECISION MAKING TO THE AUDIT FEE, AUDIT COMMITTEE ON A AUDIT QUALITY
}

\author{
Aprilya Dwi Yandari \\ aprilyadwiyandari09@gmail.com \\ Department of Accounting, Airlangga University, Dharmawangsa, Surabaya, Indonesia \\ Erina Sudaryati \\ erina.sudaryati@feb.unair.ac.id \\ Department of Accounting, Airlangga University, Surabaya, Indonesia
}

\begin{abstract}
This article writes related the purpose of writing is to measure the extent of audit fees, audit committee on audit quality in a decision making. When to pay a fee should not be done by an auditee, because avoiding the existence of a form of problem to the loss of an auditor independence. Especially for clients who have opinions other than unqualified (WTP). It may also encourage an auditee to pressure the auditor, such as the form of pressure that will replace his or her public accounting firm with another accounting firm. Fee audit and audit committee are very influential in audit quality, when the actual audit cost is higher than normal audit cost. And then, audit fee of expensive can create an incentive to the auditor to agree on client pressure in a form of report result so that it can result to quality audit. In addition, audit fees also arise over a clients business risk relationship which has important implications for the obligation of an independent auditor for an audit that has been allegedly negligent in doing so, as well as on audit fees which theoretically relate to both an audit effort and a business's risk auditors.
\end{abstract}

Keywords: Fee Audit, Audit Committee, Audit Quality, Financial Statements

\section{PENDAHULUAN}

Adanya kasus runtuhnya Enron yang terjadi dan kematian seorang auditor yaitu Arthur Anderson, saat ini profesi audit di seluruh dunia berada dibawah pengawasan publik yang cukup relatif erat atau intens. Pada sistem pemerintahan dan regulator Negara Amerika saat ini mengambil suatu langkah yang mana belum pernah dilakukan sebelumnya untuk dapat menstabilkan dan mengambil kepercayaan kembali para investor yang berada di pasar modal. Contohnya yaitu pada saat diberlakukannya Sarbanes OxleyAct pada tahun 2002 yang saat itu diterapkan suatu sistem aturan yang sangat ketat dimana aturan tersebut dianggap sebagai suatu peraturan ekonomi yang paling baik dan komprehensif. Dalam adanya suatu kasus Enron tersebut maka para auditor juga mulai membenahi suatu bentuk etika profesi auditnya.

Kasus Enron tersebut membuat para praktisi mulai berpikir tentang bentuk korporasi yang telah membuat dampak pada suatu etika praktisi serta berdampak pada semua pihak yang berkepentingan seperti emiten, dewan komisaris, komite audit, otoritas pasar modal, dan lain-lain. Sehingga yang lebih terpenting yaitu pada seorang profesi 
akuntan publik yang mana sebagai auditor dari eksternal untuk dapat meningkatkan suatu profesionalisme profesinya yang mana dapat ditunjang dengan suatu pengetahuan yang berada pada lingkup suatu instrumen derivatif dan perlindungan suatu nilai, penyusunan sistem dan prosedur pengendalian yang sesuai dengan standard akuntansi yang telah berlaku, serta dapat mengimplemetasikannya pada suatu praktek seperti GCG (Good Corporate Governance).

Selain itu juga yang sering terjadi pada suatu permasalahan dalam mengaudit suatu laporan adalah ketika kita menerima seorang klien yang mana dalam hal itu klien mencari suatu lembaga audit yang memeiliki kompetensi dalam bentuk pengalaman, serta ditinjau dari nilai suatu fee dalam pengauditan. Kita ketahui bahwa sebelum seorang klien menyetuji suatu bentuk perjanjian untuk dilakukannya audit, maka seorang klien harus menyetujui suatu bentuk perjanjian yang telah dibuat oleh lembaga audit salah satunya terkait dengan audit fee. Kebijakan suatu audit fee IAPI telah tertuang dalam Surat Keputusan Ketua Umum pada tanggal 2 july 2008, yang mana terkait tentang sauatu kebijakan yang mencerminkan tantangan yang dihadapo oleh profesi, yaitu masih adanya penetapan suatu fee yang rendah (M.Tuanakotta, 2011).

Adanya suatu penerapan fee audit yang rendag berdampak pada suatu keraguan anggota IAPI dalam menerapkan suatu standard. Sehingga adanya suatu penegasan menyebutkan bahwa benchmark dengan auditor atau akuntan lain tentang audit fee yang secara signifikan jauh lebih kecil atau rnedah. Maka dalam SK ataupun lampiran tidak dijelaskan siapa auditor atau akuntan lain dalam isinya. Oleh sebab itu penentuan fee merupakan time consume yakni suatu bentuk konsumsi waktu yang mana dari suatu perlibatan staff pada kantor akuntan publik (KAP).

Dalam membayar fee jangan dilakukan oleh seorang auditee, dikarenakan menghindari suatu bentuk masalah terhadap hilangnya suatu independensi auditor, khususnya bagi klien yang memiliki opini selain wajar tanpa pengecealian (WTP). Dikarenakan dapat mendorong seorang auditee untuk menekan auditor, seperti bentuk tekanan bahwa akan menggantikan kantor akuntan publiknya dengan kantor akuntan lain. Sehingga bentuk ancaman tersebut merupakan suatu bentuk kelangsungan hidup kantor akuntan yang mana nantinya owner dari kantor akuntan publik dapat mengalah kepada keinginan yang diinginkan oleh seorang auditee. Selain itu juga dalam menentukan suatu audit fee maka dapat melihat dalam bentuk suatu kantor akuntan publiknya. Yang mana kantor akuntan tersebut dilihat dari ukuran KAP dan Brand Name kantor tersebut.

Adanya hal itu, maka jika kita lihat bahwa audit fee akan memiliki suatu bentuk pengaruh terhadap suatu laporan keuangan. Oleh sebab itu jika kita mengingikan suatu bentuk laporan keuangan yang cukup baik dan dapat dipertanggung jawabkan maka kita dpaat melihatnya dengan bentuk ukuran KAP dan Brand Name kantor akuntantersebut yang nantinya juga berengaruh terhadap peranjian suatu bentuk auditfee. Oleh karena itu independensi auditor pada audit fee akan berpengruh terhadap suatu kualitas laporan audit. Maka dalam penulisan ini kita membahas suatu bentuk independensi auditor pada fee audit, komite audit terhadap kualitas audit dalam bentuk suatu pengambilan keputusan yang akan dilakukan.

\section{TINJAUAN PUSTAKA}

\section{Fee Audit}

Profesi akuntan publik mempunyai ciri yang berbeda dengan profesi lainnya seperti dokter atau pengacara. Profesi dokter maupun pengacara dalam menjalankan keahliannya 
akan menerima fee dari kliennya, dan mereka berpihak pada kliennya. Sedangkan profesi akuntan juga memperoleh fee dari kliennya dalam menjalankan keahliannya, tetapi akuntan harus independen, tidak memihak pada kliennya dan dalam melaporkan atau mendeteksi kecurangan harus bebas dari pengaruh fee yang diterima, karena memanfaatkan hasil pemeriksaannya terutama adalah pihak lain selain kliennya. Fee Audit Menurut Sukrisno Agoes (2012:56), komisi audit adalah imbalan dalam bentuk uang atau barang atau bentuk lainnya yang diberikan kepada atau diterima dari klien atau pihak lain untuk memperoleh perikatan dari klien atau pihak lain. Standar profesional akuntan publik seksi 240 point 1 tentang fee menyatakan, Dalam melakukan negoisasi mengenai jasa professional yang diberikan, praktisi dapat mengusulkan jumlah imbalan jasa profesional yang dipandang sesuai.

Fee audit adalah suatu bentuk pendapatan yang besarnya bermacam-macam tergantung dari adanya suatu faktor dalam penugasan audit seperti, keuangan klien (financial of client), ukuran perusahaan klien (client size), ukuran auditor atau KAP, keahlian yang dimiliki auditor tentang industri (industry expertise), serta efisiensi yang dimiliki auditor (technological efficiency of auditors). Institut Akuntan Publik Indonesia (IAPI) menerbitkan Surat Keputusan No. KEP.024/IAPI/VII/2008 pada tanggal 2 Juli 2008 tentang Kebijakan Penentuan Fee Audit. Dalam bagian Lampiran 1 dijelaskan bahwa panduan ini dikeluarkan sebagai panduan bagi seluruh Anggota Institut Akuntan Publik Indonesia yang menjalankan praktik sebagai akuntan publik dalam menetapkan besaran imbalan yang wajar atas jasa profesional yang diberikannya. Lebih lanjut dijelaskan bahwa dalam menetapkan imbalan jasa yang wajar sesuai dengan martabat profesi akuntan publik dan dalam jumlah yang pantas untuk dapat memberikan jasa sesuai dengan tuntutan standar profesional akuntan publik yang berlaku. Imbalan jasa yang terlalu rendah atau secara 34 signifikan jauh lebih rendah dari yang dikenakan oleh auditor atau akuntan pendahulu atau dianjurkan oleh auditor atau akuntan lain, akan menimbulkan keraguan mengenai kemampuan dan kompetensi anggota dalam menerapkan standar teknis dan standar profesional yang berlaku. Dari kedua pengertian tersebut diatas, maka dapat disimpulkan bahwa fee audit adalah biaya atau imbalan yang diberikan klien kepada akuntan publik sebagai imbalan jasa yang diberikan akuntan publik berupa jasa audit.

\section{Komite Audit}

Menurut Hiro Tugiman $(1995,8)$, pengertian Komite Audit adalah sebagai berikut: "Komite Audit adalah sekelompok orang yang dipilih oleh kelompok yang lebih besar untuk mengerjakan pekerjaan tertentu atau untuk melakukan tugas-tugas khusus atau sejumlah anggota Dewan Komisaris perusahaan klien yang bertanggungjawab untuk membantu auditor dalam mempertahankan independensinya dari manajemen."

Dalam Keputusan Menteri BUMN Nomor: Kep-103/MBU/2002, pengertian Komite Audit tidak diterangkan secara gamblang, tetapi pada intinya menyatakan bahwa Komte Audit adalah suatu badan yang berada dibawah Komisaris yang sekurangkurangnya minimal satu orang anggota Komisaris, dan dua orang ahli yang bukan merupakan pegawai BUMN yang bersangkutan yang bersifat mandiri baik dalam pelaksanaan tugasnya maupun pelaporannya dan bertanggungjawab langsung kepada Komisaris atau Dewan Pengawas. Hal tersebut senada dengan Keputusan Ketua Bapepam Nomor: Kep-41/PM/2003 yang menyatakan bahwa Komite Audit adalah komite yang 
dibentuk oleh Dewan Komisaris dalam rangka membantu melaksanakan tugas dan fungsinya. Komite Audit dibentuk oleh Dewan Komisaris atau Dewan Pengawas, yang bekerja secara kolektif dan berfungsi membantu Komisaris dalam melaksanakan tugasnya. Komite Audit bersifat mandiri baik dalam pelaksanaan tugasnya maupun dalam pelaporan, dan bertanggungjawab langsung kepada Komisaris.

\section{Kualitas Audit}

Kualitas merupakan komponen profesionalismeyang benar-benar harus dipertahankan oleh akuntan publik profesional. Independen disini berarti akuntan publik lebih mengutamakan kepentingan publik di atas kepentingan manajemen atau kepentingan auditor itu sendiri dalam membuat laporan auditan. Oleh sebab itu, keberpihakan auditor dalam hal ini seharusnya lebih diutamakan pada kepentingan publik (IAI, 2001). Secara teoritis pekerjaan akuntan publik biasanya dihubungkan dengan kualifikasi keahlian, ketepatan waktu penyelesaian pekerjaan ,kecukupan bukti pemeriksaan yang kompeten pada biaya yang paling rendah serta sikap independensinya dengan klien.

De Angelo (1981) mendefinisikan kualitas audit sebagai kemampuan auditor mendeteksi kesalahan pada laporan keuangan dan melaporkannya kepada pengguna laporan keuangan tersebut, peluang mendeteksi kesalahan tergantung pada kompetensi auditor sedangkan keberanian auditor melaporkan adanya kesalahan pada laporan keuangan tergantung pada independensi auditor Jadi dapat disimpulkan bahwa kualitas audit adalah kemampuan dari seorang auditor dalam melaksanakan tugasnya dalam mengaudit dan melaporkan laporan keuangan dengan sebaik mungkin dan bertanggung jawab pada kepercayaan masyarakat.

\section{METODE PENELITIAN}

Metode penelitian yang digunakan dalam penulisan artikel ini adalah menggunakan metode penelitian kualitatif. Metode pengumpulan data yang digunakan dalam artikel ini adalah studi literature dengan menggunakan jenis data sekunder berupa surat keputusan kementerian yang berlaku, dokumen-dokumen yang mendukung serta hasil dari penelitian-penelitian terdahul dengan menganalisis beberapa jurnal yang terkait dengan auditing dalam menentukan factor-faktor yang dapat mempengaruhi kualitas audit dalam mengambil suatu keputusan. Data-data tambahan litetur dikumpulkan, kemudian dianalisis dengan memahami bagaimana hasil interpretasi peneliti dalam memberikan suatu feedback terhadap berbagai permasalahan kualitas audit yang nantinya dapat memberikan saran jawaban atas permasalahan dari beberapa kesimpulan yang ada.

\section{PEMBAHASAN}



Dari jurnal yang dikumpulkan tentang besarnya fee audit diatas, maka dapat dilihat bahwasanya dalam hasil menunjukkan bahwa ketika seorang manajer percaya diri untuk bisa hadir, jumlah biaya audit yang dibayarkan oleh perusahaan dengan komite audit yang 
kuat secara signifikan lebih tinggi daripada yang dibayar oleh perusahaan tanpa komite audit yang kuat. Secara keseluruhan, hasil tersebut dapat konsisten dengan komite audit yang kuat dimana dapat mengurangi hubungan negatif antara manajerial yang terlalu percaya serta pemeriksaan suatu biaya. Selain itu juga fee audit juga sangat berpengaruh secara signifikan terhadap suatu kualitas audit yang mana nantinya pada saat auditor melakukan negosiasi dengan pihak manajemen tentang nilai fee yang akan dibayarkan terhadap suatu hasil kerja laporan auditannya, maka kemungkinan besar akan terjadi suatu nilai yang dapat menginsentifkan kepada suatu kualitas laporan pengauditan. Dimana hal tersebut dapat membuat suatu tindakan yang dapat membuat nilai profesionalisme berkurang, sehingga adanya hal itu maka akan dapat mereduksi suatu kepentingan penjagaan atas suatu kualitas auditor.

Selain itu juga komite audit juga sangat berpengaruh dalam kualitas audit dan laporan keuangan yang juga didasari oleh fee audit. Yang mana ketika biaya audit yang sebenarnya lebih tinggi dari biaya audit yang normal, dikarenakan biaya audit yang berlebihan dapat menciptakan suatu insentif terhadap auditor untuk menyetujui adanya tekanan klien dalam suatu bentuk hasil laporan sehingga dapat berakibat kepada kualitas audit. Oleh karenanya adanya suatu nilai insentif auditor dalam melakukan suatu pengkompromian atas kualitas audit secara sistematis dapar berbeda dalam siatuasi tertentu, misalnya ketika fee audit berada dia atas nilai ekspektasi auditor terhadap tingkat biaya yang normal dan ketika hal tersebut berada di bawah ekspektasi auditor.

Pada saat auditor menerima lebih dari tingkat fee normal dari seorang klien, maka keuntungannya adalah mempertahankan klien yang menguntungkan yang bias memperoleh hasil yang lebih besar daripada biaya yang terkait dengan memungkinkan suatu bentuk hasil laporan yang baik. Namun, ketika biaya audit berada di bawah tingkat fee normal, maka auditor mungkin memiliki beberapa insentif untuk melakukan suatu kompromi terhadap kualitas audit. Oleh karena itu adanya suatu kualitas audit yang baik adalah merupakan dari ketergantungan pada saat auditor menerima fee audit yang tinggi atau rendah.

Adanya hubungan fee audit selain terhadap suatu kualitas audit dan pelaporan keuangan, fee audit juga dapar berhubungan dengan suatu risiko bisnis klien yang mana memiliki implikasi penting bagi kewajiban auditor independen bagi suatu audit yang telah diduga lalai dalam melakukannya, yang mana seperti halnya pada biaya audit dimana secara teoritis terkait dengan kedua upaya audit dan risiko bisnis seorang auditor. Namun adanya pembentukan asosiasi maka dapat menjelaskan atas suatu reaksi auditor independen dalam tindakan karakteristik klien yang dapat mengindikasikan adanya risiko audit yang tinggi. Adanya suatu informasi bagi seorang auditor independen yaitu dengan mengenali dan dapat bereaksi terhadap suatu risiko bisnis klien yang dapat menyita pada suatu risiko tersebut dengan menjadi fee audit. Oleh sebab itu adanya insentif fee audit tersebut sangatlah berlaku dalam suatu hal, maka jika kita melihat bahwa dalam melakukan suatu tindakan fee audit yang dijadikan suatu pedoman baik secara moral atau tidak maka akan timbuk suatu nilai bentuk independensi yang ada pada kita. Termasuk saat kita melihat bahwa dalam manajemen suatu perusahaan jika ingin melakukan suatu hal terkait dlaam suatu pelaporan keuangannya dengan melihat nominal fee maka akan berkurang nilai independensi atas suatu profesi. Pada seorang auditor independensi yang ada salah satunya dalam fee audit yang dapat berpengaruh jika kita melakuakan suatu tindkaan pengaduitan yang berada dalam perusahaan, maka kita sebagai pihak dari eksternal auditor akan berkolaborasi dengan pihak audit eksternal perusahaan. 
Seperti yang dapat kita lihat bahwa ketika adanya suatu kebijakan, dimana setter kebijakan pada eksternal auditor dan audit eksternal perusahaan ingin mempertimbangkan atas suatu pengaturan terkait sumber yang merupakan alasan atas faktor yang tepat dalam hal mempertimbangkan ketergantungan atas keputusan yang mana saat suatu bentuk faktor harus dimasukkan ke dalam kebijakan. Maka IAFs dan Audit klien mungkin juga ingin mempertimbangkan tentang bagaimana eksternal auditor bereaksi terhadap suatu pengaturan atad sumber yang berbeda, yang mana ketika manajemen memiliki nilai relatif insentif yang tinggi dalam mengelola pendapatan atau pada saat suatu faktor risiko lainnya yang melekat serupa timbul.

Selain itu juga fee audit pada saat kondisi dimana menggunakan jasa Arthur Andersen ditemukan bahwasanya terdapat suatu hubungan antara biaya audit yang dibayarkan kepada auditor baru dan selama masa dengan Andersen. Sehingga adanya penelitian tersebut maka dapat memberikan suatu bukti tambahan tentang pengaruh masa auditor pada auditor pengganti yang memiliki persepsi berisiko. Dengan mengetahui masa auditor dengan auditor sebelumnya daripada melihat masa jabatan dengan auditor yang saat ini, adanya hal tersebut telah dapat mengatasi permasalahan yang terjadi dengan sifat endogen kepemilikan seorang auditor. Pada saat masa auditor dengan menggunakan jasa dari Andersen yang saat itu menjadi meningkat, maka dapat berdampak pada auditor baru yang mana dikenakan biaya audit yang lebih tinggi. Yang mana hal tersebut akan menjadi bukti bahwa auditor baru dapat merasakan masa ketika dengan masa kerja jasa Andersen yang sebagaimana merupakan suatu faktor risiko.

\section{KESIMPULAN}

Fee audit adalah suatu bentuk pendapatan yang besarnya bermacam-macam tergantung dari adanya suatu faktor dalam penugasan audit seperti, keuangan klien (financial of client), ukuran perusahaan klien (client size), ukuran auditor atau KAP, keahlian yang dimiliki auditor tentang industri (industry expertise), serta efisiensi yang dimiliki auditor (technological efficiency of auditors). Fee audit sangat berpengaruh terhadap suatu kualitas audit yang mana nantinya dilakukan pada saat auditor melakukan negosiasi dengan pihak manajemen tentang nilai fee yang akan dibayarkan terhadap suatu hasil kerja laporan auditannya, maka kemungkinan besar akan terjadi suatu nilai yang dapat menginsentifkan kepada suatu kualitas laporan pengauditan. Namun untuk pada komite audit yang juga sangat berpengaruh dalam kualitas audit dan laporan keuangan juga didasari oleh adanya fee audit. Ketika biaya audit yang sebenarnya lebih tinggi dari biaya audit yang normal, dikarenakan biaya audit yang berlebihan dapat menciptakan suatu insentif terhadap auditor untuk menyetujui adanya tekanan klien dalam suatu bentuk hasil laporan sehingga dapat berakibat kepada kualitas audit.

Dilain sisi, dari fee audit juga timbul suatu hubungan dengan suatu risiko bisnis klien yang mana memiliki implikasi penting bagi kewajiban auditor independen bagi suatu audit yang telah diduga lalai dalam melakukannya, yang mana seperti halnya pada biaya audit dimana secara teoritis terkait dengan kedua upaya audit dan risiko bisnis seorang auditor. Oleh sebab itu pada saat yang terjadi pada kasus penggunaan jasa Arthur Andersen, masa dimana seorang auditor menggunakan jasa dari Andersen yang saat itu menjadi meningkat. Dikarenakan adanya sesuatu yang berdampak pada auditor baru yang mana dikenakan biaya audit yang lebih tinggi. Sehingga penggunaan jasa pada Andersen tersebut memiliki suatu bentuk resiko. Namun jika kita melihat dari dasar fee audit pada tanggung jawab hukum dan premium fee Big 4. Ditemukan bahwa fee audit dapat 
meningkatkan sesuatu yang menoton sebagai kekuatan atas kewajiban hukum dalam suatu negara yang akan membaik. Karena kewajiban atas hukum auditor akan diperkirakan akan meningkat dengan kualitas atas hukum, yang mana kondisi pada kegagalan audit, auditor dapat mengenakan biaya yang lebih tinggi sebagai kompensasi atas kewajiban hukum yang lebih tinggi.

\section{DAFTAR PUSTAKA}

Agoes, S. 2012. Auditing ( Pemeriksaan Akuntan) oleh AKntor Akuntan Publik Edisi ke 4. Jakarta: Lembaga Penerbit Fakultas Ekonomi Universitas Indonesia.

Bambang, H. 2012. Pengaruh fee audit, rotasi KAP dan reputasi auditor terhadap kualitas audit di Bursa Efek Indonesia. Ekuitas: Jurnal Ekonomi dan KeuanganVol. 16. No.1: 84-103

Burch, T.K, dkk. 2007. The association between audit-firm tenure and audit fees paid to successor auditors: evidence from Arthur Andersen. Auditing: A Journal of Practice \& Theory Vol. 26. No. 2: 95-116

DeAngelo, L.E. 1981. Auditor Size and Audit Quality. Journal of Accounting and Economics. (Desember) 183-199

Elizabeth, A.R, dkk. 2009. The impact of audit committee quality on financial reporting quality and audit fees. Journal of Contemporary Accounting \& Economics Vol. 5: $20-33$

Jenny, G.S, dkk. 2006. Relation between external auditfees, audit comitte characteristics and internal audit. The Authors Journal Compilation Vol. 46: 387-404

Jonathan, D.S. 2011. Is the audit fee disclosure a leading indicator of client's business risk?. Auditing: A Journal of Practice \& Theory Vol. 30 No. 3: 157-179

Hirsch, J. 2002. Enron audit fee raises some brows. Los Angeles Times (January 23): A.1

M.Tuanakotta, T. 2011. Berpikir Kritis dalam Auditing. Jakarta: Salemba Empat. 